\title{
粉体工学会第23回夏期シンポジウム総合討論 粉体プロセスと界面現象
}

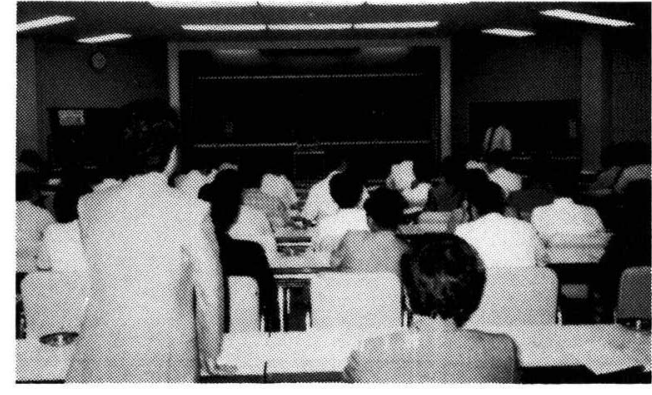

シンポジウム会場

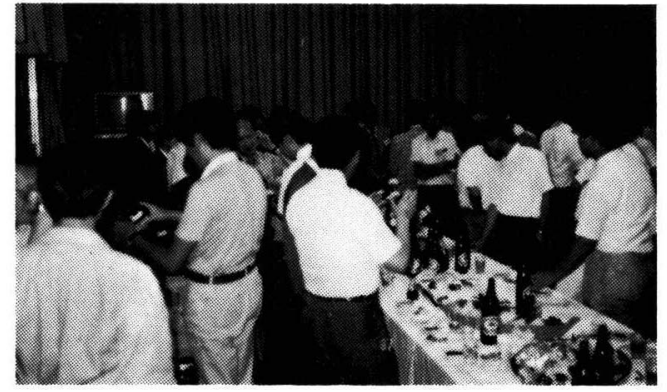

䅰親会会場
井上（東大）との夏期シンポは “粉体プロセスと界 面現象”という表題になっておりまして，扔話をうか がっておりますと, 界面現象の物理化学的，あるいは 表面化学的な観点でつってんだ研究をお話くださった 方もでざいますし，それから，比較的応用面で，粉体 プロセスの側から色々な問題をお話いただき，そして， それに実は界面現象が非常に深くかかわっているとい うケースもあったかと思います。また，一口に界面現 象と言いましてあ，例えばレオロジー的な測定のよう な側からみた側面から， 1 個 1 個の分子や原子のオー ダーで，どういった作用がおよぼしあっているか，と いうようなところまで, マクロからミクロまで, 非常 に幅があったように思われるわけです。そういう意味 で，昨日扔願いしましたように，各講演者の方にほん の 1 ～ 2 分で結構ででざいますが，まず，その辺の将 来の見通し，例えば今は界面現象をやっているけれど あ将来的にはこういう風な粉体プロセスにうまくむす びつけていきたい，とか， あるいは粉体プロセスの中 のどういう部分をあう少し深めていきたい，などとい ったところを最初にうかがって，討論の手がかりにし たいと思います。

近沢（都立大）私が大学にまいりました時には，い わゆる戦後の食料事情がわるい時点で, 肥料が化学工 業にとって重要な産業となっていました。そして，そ の肥料が吸湿・固結する，というのが問題になってい
るので，それを界面化学的にやってみないか，という のがスタートだったわけです。その界面化学的にとい うのが, 結局, 水が吸着して溶けたり, 吸湿して付着 ・凝集・潮解・固結が起乙るわけなんですが，その水 が 1 個の水では物を溶かすなどの，いわゆるバルクの 水の性質を持っていないのに対して，それがどの程度 の集合体になったら，あるいは固体表面にどれくらい の厚みを持ってきたら物を溶かすのか, バルクの質を 示すようになるのか，そのあたりをちよっとやってみ ようということだったわけです。それで，表面が多く なくてはいけない，その意味で粉体を取り扱うという ことで，粉体プロセス—粉体を作るとか分けるとか 造粒するとか, あるいは改質して機能を持たせるとか いう最終目的を持っているわけではなかったわけです。 私が粉体工学会に入っておりますのあ，いわゆる様々 なプロセスにおいて様々な界面現象が起ってトラブル の要因となっていたり，様々な問題を起しているわけ ですが，そういったいわゆる吸着水分が作用因子とし てどのくらいの強度が出てきて, どのくらいの問題を 起てしているのか, というあたりがわかれば，それを 物の見方として吸着水膜のとらえ方が多角的に見られ るのではないか，ということでして，私自身は界面現 象が中心でやっております。そんなとてろです。

臼井（東北大・選鉱製練研）私，昨日乙てで，DLVO 理論, コロイド凝集理論のアウトラインをお話させて 
いただいたのですが，DLVO 理論にせよ，へテロコ アギュレーションセオリーにしてあ二体問題で, 二つ の粒子が近づいてきた時によ゙ういうことが起てるか, というあのです。それはそれでよろしいのですが，昨 日のお話であたくさんありましたように，粉体工学で は濃厚なサスペンションをつかうとか, 系全体として は粒子がたくさんありますので，あるいは DLVO 理 論で説明がつくところあありますし，全体でみるとそ れではなかなか説明がつかないとてろあどうあありそ うなわけです。ですから，二体問題と系全体でみたと きに，理論的にうまく行く場合はいいのですが，いか ない場合はこういうのがあるんだというようなお話を むしろお聞かせいただければありがたいと思います。 それからコロイドの疑集で私あへテロコアギュレーショ ン一一種粒子間の疑集——に興味を持っていますの で，実際問題としてはこういう括もしろい問題がある んだ，とか，乙ういう問題がわからない，とか，そう いうお話を，実際の粉体を取り扱っている方々からお 聞かせいただりればありがたいと思います。それから， コロイドケミストリーというのはだいたい液中に粒子 を分散している系を主に使うのに対して，粒体工学の 方では割合乾いた方を使うんですね。それで，ててで お聞かせいただいた話で大変興味を持ったのは空気中 でのチャージ—まさつ帯電一というのはどうも 手品みたいな得体の知れないあのでチャージを持って しまうので，あれはどうあ泥沼でやってあおあしろく ないんだろうと思っていましたら，案に相異して空気 中でおびる帯電と水中のチャージが共通の性質を持っ ていると聞いてたいへん興味を持ちまして，ての辺を 少し勉強したいと思っておりますのでよろしくお願い します。ての辺でひとつ。

小石(東京理大) 比電荷量の測定については, 私も 一緒にやっておりますので, 私の方からコメントを申 し上げたいと思います。私共は臼井先生などを中心と しまして界面電気部会でら電位を勉強してきたのです が, 乾式で粉の表面チャージを計るというととを前か らやっておりまして，その関係で東芝の小口さんと一 部共同研究をいたしまして, 電位と空気中のチャー ジの問題をまとめてでざいます。それは日化誌 (No６ 1984)に書いた私共の協同の仕事，それから材料技術 に書いたものがでざいます。日化誌の方は超微粒子の 特集号で，その中で様々な方が様々なととをやってお りますが, 私共は日化誌の同じ号にあう一つカーボン ブラックとチタンの混合に関する報告をしておりまし て, 文献を一つ追加させていただきたいと思います。
それから，三協電業の方の考え方は，小口さんのブロ 一オフの考え方一鉄粉之まぜて考えるというのと違 いまして, 単粒子一一種類の粉体について, 粉塺を 発生させて，それからその表面チャージを計るという， それにプラズマ荷電を使うという考え方です。まだて ちらの方は，多少係数等掛けないと表面積が計算でき ないのではでざいますが, プラズマということで粉体 表面の，あるいは固体表面の改質にプラクティブライ ンという形で害用的に使われております。したがって そういう風なチャージをキャリアを使って考えるか, それとも分散して粒子一個一個の表面㑸電をして, それをファラデーケージでとらえて考えるか，という 考え方が私共の考え方ででざいます。

山本 (東大生研) 私たちのところでは, 気相での粉 体の挙動について長くやってまいりまして, 皆さんで ぞんじのように，気相では特に粒子同士の衝突，ある いは壁面との衝突などで粒子が帯電してしまって, 場 合によっては粉痤爆発とか, あるいは輸送中に管が閉 塞してしまったりとか, 様々な問題が出てまいりまし て，ハンドリングしている間に思うようにいかないの は全部静電気のせいにしたりしてまいりました。静電 気については，以前多少はやっていたのですが，よ゙う あ，先ほどお話がありましたように，泥沼に足をつっ 込むようなあので，なるべくやりたくない，というこ とで避けて通ってまいりました。とてろが二年程前に, オランダの方へ一年程行きました時に，向うであその 問題が出まして, やはりてれからは避けて通るわけに はいかんと，だから何か手をつけろということになり ました。しかたがないので様々文献を読ませていただ きましたけれども, 気相中の粒子の帯電の取り扱いで はほとんどの文献が粒子の集団を扱っていて，一個一 個のチャージを計るてとをしていないわけです。全体 で, トータルでマイナスのチャージ，プラスのチャー ジとか, 電荷の量とかの議論をしておりまして, てれ では基本的には粒子のチャージについての解明ができ ないのではないかと考えまして, 何とか一個一個の粒 子のチャージを計って, そてから基礎的なデータが得 られないが，ということで，そのためには少し大きい粒 子ということで $3 \mathrm{~mm}$ くらいの粒子を一個づつ金属板 にあてまして、チャージを計る，という方向で計画し たわけです。今考えているのは, 粉体工学ではファイ ン化がどんどん進んでおりますので，なるべく小さい 粒子まで計れるような方向でして, その方で今計画 しているとてろです。

竹内（花王）私の発表は多くの方々がお話になった 
ような研究内容と少し趣の違った内容になってしまっ たかと思うのですが，といいますのは，粉を作るなり， 加工するなり，あるいはそれを分散体として最終商品 として使うというような, いわゆる川上の研究, 川中 の研究, 川下の研究という分類をいたしますと, 私が いま一番興味を持ってやっております川下の研究とい うのが, この研究会では少しマイナーな部類に属する というようなととで, あう少しそちらの研究の方が大 勢いらっしゃると, 様々ディスカッションができてい いのですが。それからあう一つ, 粉の大きさで, 大中 小と分類するとしますと, 大きい方の研究が多いよう です。トナーなどですと, キャリアの大きいのとトナ 一の小さいの, というのがあるにはあるのですが, そ れからまたトナーの中にあ非常に小さなカーボンが分 散されているとか、、グネタイトが分散されていると かそういうことがあるとは思うのですが，あまりはっ きりとは，それについての研究が表に出ててないとい うようなととで, 私としては, いわゆる粉の大中小の 小の方に興味があるのですが, てれについてもての研 究会ではマイナーな部類に属しているので, てれから あっとその分野の研究者の方に出てきてあらえるとた いへんうれしいと思っております。我田引水的な表現 になってしまいますが，てれから非常に重要になる分 野ではないかと思うのですが, 研究者がかなり分散し ておりまして, どてへ行ってああまり居ないので, どてかに集中しませんとなかなか進むものも進まない のではないかというように少しいらだっております。 今度は改質の研究グループというようなことも進んで いるようででざいますので，期待させていただきたい と思っております。

岡本(東大) 私の場合は乙れまで固体一固体の問題 を主に扱っておりまして，その際，粒子としての側面， つまり不連続性があたらす不規則さとか不確定性, 非 線型性, という問題の解決に追われてきたので一い ます解決しているわけではないんですか一そのうち に、今拓話がありましたように粉の方はあっと細かくな っていっているということで，あれよあれよというょ うな感じです。またその, 今申しました不連続の問題 というのはまた性格が変ってきているように思います。 また，そういう場合に界面のはたす役割というのは非 常に大きくなってきているように思います。是非そう いうことについての情報を得たいということで今回て の夏期シンポに参加させていただきまして，そういう 意味で，ただ今拓話がありました超微粒子というよう なととについても何かお話がうかがえると非常にあり
がたいのではないかと，そのように思っております。

武崎（バブコック日立）私は入社以来ての高濃度ス ラリーということにかかわって研究を進めてきたわけ ですが，実用化ということになりますと，薬剤がコス トに対して占める割合が高いわけで，乙の界面活性剂 では $0.5 \sim 1.0 \%$ (乾炭あたり) 加えているような情況 なわけですけれども，乙れは，使う側からすれば極力 少なくして、スラリー自体の値段を下げたいというとと になるかと思うわけです。そてで, 今現在進めている 中でひとつ念頭においておりますのは，いかに活性剤 を有効に吸着させて，乙うした濃厚な固液の分散系の 中で作用させるかということです。今回の発表に関連 して言わせてもらいますと, 従来は, 発表の中で申し 上げたように微粒となりやすい灰が存在することで, 表面位子同士の凝集を, ワンクッションおくことで 進まなくさせているという効果があったわけですけれ ども, さらに今度, 脱灰ということで微粒の灰がなく なった状態では, その灰分子の微粒子をいかに一微 粒の炭分子というのは非常に凝集しやすい方向になる わけですが—それを凝集させないようにするか，と いうことでそういった粒子の大きさの違いでそういっ た界面活性剤がつきやすいのか, あるいは表面の組織 のちがいで有効な界面活性があるのか，という点を，

今, 始めていまして, その辺について何か討論できれ ば，と思っております。

平崽（北大）私共は液中造粒現象というのを基礎的 な面から追っているわけですが，液中造粒というのは 選択的な造粒ができると考えられるわけです。てれは 粒子間に負の毛管圧が働く条件で造粒体が形成される ということから，浮選などに比べるとかなり，選別性 という面でみると, よりよい効果があるのではないか と思われます。また, 球状のペレットを作ってやって 簡単にふるい分けなどで粒子を回収できるということ から固液分離などの面であ応用があると考えられます。 それから, 廃液中の油なんかを回収しようという場合 に, 逆にそういう液中造粒というのは応用できると思 います。また，球状の造粒産物を得るという目的を主 体とした応用分野ああるというわけで，そういったと ころを考えますと, 選鉱・選炭・水処理あるいは医薬 製造とかいうように，応用範囲はかなり広いあのであ ると思うのですけれよ゙す，実際にてれを実用化しよう とする場合になかなか簡単には実用化できないわけで すね。ひとつとしては, 液中造粒現象というのが, 粒 子の界面化学的团子, あるいはその圧密性, 擋拌場の 因子、それらが複雑に作用して造粒現象が進行してく 
るわけで，それらがそれぞれ目的のプロセスによって それぞれの操作因子というのが複雑作用しているの でなかなかてての团子をてうやってかえればてうい う産物ができますよ，というようには現在のとてろ致 っていません。そてで我々は，そういう液中造粒現象 を実験的あるいは理論的な考察を基にして, 少しでも 明らかにしょうではないか，ということをやってきて， 除々に成果が上ってきているとは思うのですが，さら に詳細な造粒プロセスというのは, 今後もうちょっと 厳密なモデルなんかを基に検討していかなければなら ないのではないかと考えております。

鈴木（三井サイアナミド） 今回は, 井上先生のおす すめによりまして, 実は初めて参加させていただいた のですが, 従来私共のやっていたてとが原理というこ とにかかわりながら研究を進めている姿をお聞きし まして、たいへん勉強になったと思っております。先 程も括話しましたが, 浮選が生まれて60年というこ とですが, 私の経験しているのはその半分にあおよば ないというまだかけ出しということになるかと思いま す。様々なフローテーションのてとにかかわり合って まいりまして, どうあ突き詰めてまいりますと，水相 での様々な分離を扱う，と考えますと，水中にありま す固体なり，イオンを含めて，ということになるかと 思いますが，そういうあのと水とのかかわり合い，乙 れがひとつのポイントになっているのではないかと思 います。といいますのあ，どうしても薬剤が力ギだと いって一職業柄そういうことを言っている感じにな るわけですけれども—薬剤によっていかにして水之 固体の水和を断ち切って, 逆棌ちちらを疎水化するか ということに関係が深いんじゃないかという風に見て おりまして，乙の点で従来の経験ということから，さ らに原理を調べながらその条件を探って行くてとが今 後の, 様々な場合のフローテーションを広げる意味で, 大変重要なポイントになっているのではないかと思い ます。たまたま私共の会社ではいわゆる高分子凝集剤 というのをやっておりますが，乙れは分子量で言いま すと 2000 万とか，そういう大きなあのが主体になる わけですが，乙れをなんとか水に溶かすというととを やって，水に溶かして使うわけです。どうあての場合 も, 水和というのが問題でして, 一番水に溶ける, と いう条件が様々な観点から見まして，係り合いのある てとだと思っておりまして，そういう点からも水和と いう問題が、私のてれから大いに勉強しなければな らないテーマになっていると思いますんで，ての点で また皆様の様々な教えをてうむりたいと思っており
ます。

恒川（北大）私, 浮選を始めて 15,6 年になるので すが, 最初, 泡に固体がついて浮いてくるというのは 目で見ててわかる，極めて簡単な現象ですので，単純 な私向きだなと思って始めたんですが，実際に研究を 始めてみますと, 浮選というのは固体・液体・気体之 いう三つの相がいつあ界面としてかかわってくる。ま た, 鉱物自体む複数ある, というので極めて複雑な系 なんで，とてもそういう系をいきなり取り上げるわけ にはいきませんので，適当な鉱物を選んでは固体と液 体の界面, 例えば捕集剂の吸着の仕方ですとか, 表面 の需れの問題ですとか, そんなととを一生懸命やって きたわけです。しかしながら, どうあ実際の現場で行 われている浮選操業之離れているなあという後めたさ を常に持っておりまして，何とか実際の現場で行なわ れている系に近い形で研究を進めたいと思いまして, とりあえず二つの鉱物が共存している所でどんなてと が起てっているかをやってみようといって始めた結果 を今日括させていただいたわけです。ただ，てれか らの研究の方向を考えますと，あっと実際の現象に近 い系を取り上げて行きたいんですが, 実験手法として はどうしてあ限界がありますので，ある程度単純な界 面現象を積み重ねて研究していくしかないだろうと思 います。ただ，実際の浮選操業ではそういった界面現 象が複合的に表れているわけでありますので，そうや ってつかんだ単純な条件下での界面現象を, よ゙うやっ て複合一総合的に把握したらいいのかというのが今, 私にとっての一つの大きな課題となっております。ま た, 我々はどうしてあ研究しやすさという面で, 平衡 状態で実験して，それで結果を解釈してしまおうとい うたいへん虫のよいてとをやっているわけですが, や はり実際には過渡的な状態で行なわれている場合も多 いものですから，そういう過渡状態での界面現象をど うやってとらえていくか，というのを例えば速度論的 な視点などを入れて少し研究してみないといけないな あ,ということを感じています。

小石 どうあありがとうございました。討論に移る にあたって，議論をかみ合わせるために様々な分け方が あるとは思いますが，まず最初にドライな系での様々 な議論をして，それからウェットな系の議論をする， というょうに分けて進めていきたいと思います。最初 に臼井先生から近沢先生へので質問があるようなので, まず扔願いしたいと思います。

臼井 近沢先生におうかがいしたいのですが，例え ば $\mathrm{NaCl}$ の結晶があると, 表面は陽イオンの方が引っ 
込んで，陰イオンが少し外へ出ると，そうすると少し 安定化されるという話を，私すよく聞くのですが，何 故そうなるのか, ちょうど先生がテキストにお書きにな っていましたので $(p, 6, l 3)$ ，簡単な説明をお願いした いのですが。

近沢 結局, いわゆる食塩なんかですと， 6 配位で すからフラットな面では一つの方向が切れている。で, そうしますと陽イオンと陰イオンの分極率というのは だいぶ違いまして—分極率というのはどれだけ電子 雲の歪みが生じているか, ということでして一陰 オンの方が内側の $\mathrm{Na}^{+}$に分極されて, 下側に $\delta^{-}, \delta^{+}$ になるわけです。 $\mathrm{Cl}^{-}$イオン自体が, 簡単に言ってし まえば双極子モーメントを持つようになるわけで，そ れに対して $\mathrm{Na}^{+}$イオンの分極率は小さくて，陰イオン による $\mathrm{Na}^{+}$インの分極というのは少ないわけです。 で, てれをずっとならべてみますと，陰イオンに対し ては上の方が $\delta^{+}$, 下の方が $\delta^{-}$になるわけで, その $\delta^{-}$ が 2 層目の陰イオンとの電気的な反発を生じて, 外側 に陰イオンがうごき出すと言うことになります。ベン ソンがエネルギー計算をして結局ての中心位置がもと あとあるべきとてろからズレてしまっているわけです が, それが $0.2 \AA く ら い に$ 離れるというようにされて います。まあ, そういう形で電気二重層になっている 方が安定になっているんだということで，その根源は やはり分極というかたちで, ですからてれが Li - Cl, Li-Brなどの方が変位が大きくなっているわけです。 臼井 そうしますと, 電気的な反発で, 下の $\mathrm{Cl}$ か らの反発によって上が持ち上って, $\mathrm{Na}$ が下へ引かれ て，というわけですね。そのエネルギー計算というの は静電気的なエネルギーを計算して, ということでし ょうか。

近沢 そうです。で, こういった表面的なひずみは 5 層くらいにおよんでいるということです。

臼井それは $\mathrm{NaCl}$ の他にも, どんな化合物であ全 部そういう傾向はあるわけですね。

近沢 たぶんそうだと思います。分極率によって差 が出てくるんだろうと思うんですけれどあ。

小石 固体表面に関することで他に何かありません でしょうか。なりれば次に静電気に関する問題に入り たいと思います。

臼井たいへんつまらない話なんですが, 例えば粉 が空気中でマイナスのチャージを持ったとしますね, それが何か, 湿気とか水があると逃げてしまうという 話ですが, 確かにそう思うんですけれどあ, 例えば 非常に絶縁性のよいビーカーの中に水を入れて, 負の
チャージを持った粉をその中に漬けたとします。そうす ると, そのビーカーは電気的に全体としてマイナスの チャージを持つでしょうか, それとも空気中で握びた 電荷は逃げてしまうものでしょうか。

山本 粒子が帯電しやすいというのは, 我々が扱っ ている粉はたいてい絶縁体でして，それに例えばイオ ンなり電荷なりが付着しますと, 抵抗が高いあのです から全体に拡散しないで，そてに何かそれを打ち消す イオンなり電荷なりがてない限りはプラスならプラス のままでいる，と考えられているわけですね。てれに 対して金属粒子の場合は, 非常に導電性がよいので電 荷が表面全体に拡散してしまう，ということで，どち らかと言うと我々が扱っている粉体の方が帯電現象が 顕著に出てくるというのがまず一つなんですね。それ を水の中に入れた場合にはたぶん，表面に水酸基イオ ンなり水素イオンなりがくっついたりするんじゃない かと思うんですけれどあ，そうしますと，粒子の表面 についている電荷というのは, 液中では, 何かそうい う溶質で中和されてしまうというように思うのですが。

臼井 むとあとビーカーの中に入っている水は電気 的に中性ですね。そてへマイナスの電荷がのった粉が 入ってきて, 水の中でそれを中和するために币がくると， 水の方にまた $\ominus か ゙$ 残ってしまうわけですよね。

山本 ええ, 溶液全体としては電荷が増えるてとに はなると思います。理想的な系で, そのビーカー全体 が何かで絶縁されて, 完全に浮かした状態にあればで すね，粒子のチャージ量と同じ電荷がビーカー全体に は残ることになると思います。ただし，ての場合，よ゙ ての部分にマイナス荷電が残っているのか, というこ とはわかりません。例えば 1 個の粒子の電荷を計る場 合であ, ファラデーヶージなどで観測しまして全体と して正のチャージを持っていると言うわけですけれど あ，表面の微細な電荷分布を見ますと，ある部分は正 に，またある部分は負にといった具合に分布しており まして，それで，全体としては正であるとか負である とか言うことになるわけです。

臼井 粉にチャージを帯びさせて水の中へ入れると 負のチャージのたまった水溶液が, つまり電気的中性 の保たれない溶液ができるのか,できないのか, とい うことを考えているわけですが, ふつうはまあだいた いみんな逃げてしまう。それを非常に絶縁性のよいビ 一カーに入れたらですね, 電気的中性の保たれない溶 液のできる可能性はあるわけでしょうか。

山本 ビーカーを含めて, トータルで正とか負とな るわけですから，溶液自体が電荷を持つてとになるか 
どうかはわかりません。

小石 ちょっとコメントになるかどうかわかりませ んが, 以前, ナイロンとかポリエチレンの $5 \mu \mathrm{m}$ の粒 子を真空脱気して, それから湿潤熱を計ろうとしたて とがあります。そうしますと，ナイロンはどうあ疎水 性粉体なむので水に浮くんですが, 真空脱気して水和 水までとってしまうと湿潤熱が $1000 \mathrm{erg}$ くらいにな ります。 $500 \mathrm{erg} / \mathrm{cm}^{2}$ が親水性, $80 \mathrm{erg} / \mathrm{cm}^{2}$ が柾 水性粉体と言われているんですが，再水和熱と濡执熱 が一緒に入って，解釈に困ったてとがあります。です から, 水というのは何かチャージなどにあかなりから んできそうだと思うわけです。小口さんの昨日の発表 でもと電位とブローオフ法の直線関係が $45^{\circ}$ でよく成 り立つ, というのが何かその水がからんでいるような 気がします。

界面の方が少し少ないようですが, 次に, 花王の竹 内さんの方から㹉いしたいと思います。

竹内 世の中が軽薄短小と言われるようになって長 くなりましたが，実際にデバイス化されたもの，ある いはそれを作ったシステムあどんどん小さくなってお りまして，したがって，それを構成します材料むどん どん小さくなっております。粉についても同じでして 例えば, トナーの粉む解像度をよくするために小さくし ようとか, 磁気メディアあ高密度化するために粉を小さ くしょうというような全体の流れがでざいます。とて ろが，ただ単に粉を小さくして行きますと，あるとて ろで今までの技術ではいくら苦労してもなかなか理論 的に予想されるようなよい特性が出ててないというょ うなととが起こります。例えば BET 比表面積で 20 〜30 というとてろではうまくいっていたんですが, 40 〜 60 とか, ただ単にそういう数字ではあるんですが, そういった小さいあのを使いますと，分散がうまくい かないためにかえって特性が悪くなってしまうというょ うな状況がよくございます。ですから，その辺につい ては今までの技術の延長でなく，少しひと捻りした技 術が必要になってくるというような感じがいたします。 それから，ただ単に細かくなるというだけでなくて， 材料としても，例えばバリウムフェライトやメタル粉 などは自発磁化の問題や形状の問題で非常に分散が難 しいというょうな，困った材料がいくつか出てきてい まして，それを何とか少し工夫してうまく使いてなそ うということで，昨日，すこし工夫した表面処理材の 問題を御紹介させていただきましたが，あれとてまだ， なかなか十分思うとてろまでいっておりませんで，あ っともっと充填性を上げる，とかいうような技術が必
要です。それから, 粉そのあのについてあ充塤性を上 げるためにただ単に今まででき上ったような分布の針状 粉を使っていたということでは限界がきておりますむ のですから，充填性を上げるために針状比を少し，落し てであよいから紡錐形にするとか，または，ライスラ イクといっておりますけれどあ，充填性を上げるよう な粒度分布の制御というような技術が，粉を作るとい うような立場からは要求されております。それで，そ ういう小さな粉を作るとか使うということについて, 私共としては興味を持って研究を始めておりますが, そういうあのをただできた，作ったというだけではな しに，それがそれなりにいいんだ，という理届付けを， 後からであいいですからしておきませんと，様々と落 し穴にひっかかるという可能性もあります。最近は特 に表面の分析機器というあのが発達してきております ので, 新しくできた粉体が従来のものに比べてどうち がうのか, ということを分析できるのではないかと思 います。例えば, 蒸発法のメタル粉はどういうわけか メタルがほとんどで, 非常に薄い酸化皮膜が強く, 耐 食性が非常によいという結果だけがわかっております が，なぜかということがまだわかっていません。その 構造などをはっきりするてとができますと一蒸発法 のメタル粉というのは粒度分布が大きくて実際には使 えないんですが一湿式法で作った粒度分布のいい, 細い粉をそういう手法で皮膜を作って防食を十分にす るなどといったようなてとが，分析をうまくするてと でできるんじゃないか，と考えています。それから， 表面エネルギーのコントロールの問題ですとか, 反応 させるための，無機物の表面にどんな官能基があるのか， とか、どんな水和水が挙動しているのか，など，細かい 分析をしておきませんと，本当の，うまい利用ができ ないのではないかと思うわけです。それから，製造の 方についてですけれどあ, 単位操作でむって様々加工 度の高い商品を作る場合には, 最終的な歩留りは, 数 多くの操作の, 各々の歩留りの積になってしまいます ので, 各プロセスで歩留りを十分上げるくふうをしま せんと経斉的にあってまいりません。そういう観点か ら，今までどうりの単位プロセスで，そのまま一つづ つ歩留りをあげるというととでなくて, 一つのプロセ スの中で今まで二つまたは三つやっていたようなプロ セスをいっぺんにやってしまうということを考えるわ けです。そこで歩留りがよければ急激に歩留りが上る んじゃないかと思います。乙れは，まあ，製造現場に 近いところにおります人間の発想ででざいますけれど あ, 工業化ということになりますと, こういうことで 
経済的に合うか合わないかの㞳路にたってしまうよう なととが多いものですから，そういう単位プロセスと いうようなあのをあう一つ見直して，あっといいあの を作ってしまうような，発想の転換といったようなて とを一具体的なアイデアはないのですが一一考えて みたりしております。

小石 ちょっと, 私からひとつ, 竹内さんにお聞し てよいかどうかわかりませんが、花王というのは, 界 面活性剤の溶液系から分散をせめる考え方が強いのか, あるいは粉からせめているのか，というのがいつあ気 になるんですが, 個人的には花王というのはどちらか というと溶液系からの分散のせめとか素材の開発に強 いという印象を持っております。それで, 固体の粉末 をいじっている人が非常に少ないと考えるわけなんで すが，最近ではいかがでしょうか，ちょっとお答えに くいかも知れませんが。

竹内 先生のおっしゃられます通り, 粉の表面から せめるというやり方での商品開発は水系からのあのに 比べますと，少ないととは確かです。ただいくつか例 がございますのは, 例えばセメントの減水剂がでざい ます。乙れはある程度成功いたしまして，パイルとか ポールとかの強度アップというようなとと, 新幹線の 架橋をより細くしてあ丈夫だからセメントの節約にな るだとか, いうことで,一つ大きな商品となっていま す。それから，あまり目立ってはおりませんが，色材 関係, 顔料の分散のようなとと、それから私共が少し 手がけております磁性粉の分散の問題，乙の扨が主な とてろかと思います。まだ小さいのは他にああります が。

井上 私あ実は小石先生がおっしゃったようなとと をお聞きしてみたいなと思っていたんですが，磁性材料 を一一竹内さんから昨日括があったわりですけれど あ一一粒子をどういうふうに並べるか，ということあ 問題なわけですが，個人的にうかがうと，ディスクの ようなものではランダマイズして、針状結晶をランダ ムに並べるということなんですね。テープのようなも のでは真直ぐ並べると。例えばランダマイズするので あればですね，まずひとつ打聞きしたいのは，針状結 晶でああまり長すぎない方がいいのか，という気がす るんですが，それから，細長い結晶を作るというのは たぶん磁気モーメントを高めるために必要なととだと 思うんですが，その辺の兼ね合いはどうなっておりま すんでしょうか。

竹内 ご指摘の通り, ランダマイズするのに針状結 晶を使うのは不利ではないかと，おっしゃられる通り
ででざいます。ですから，テープ類で一方向に配列さ せようというときには針状比が $1: 10$ ですとか，割 と長いむのが好まれて使われるわけですが，それに対 して円板のフロッピー, ハードディスクの場合は実際 にそれほど長い必要がなくて，少し短めのものを使う ということで, $1: 6$ とか $1: 7$ とかいうあのが使わ れるようになってきているかと思います。ただ実際の マーケットの大きさで言いますとテープ類が圧倒的に 多いむのですから，ディスク用に小量の磁性粉をわざ わざ作るというのがちょっと大变な面むありまして， 今までにある，作られた針状の磁性粉の中から最適な あのをとりあえず選んで使って抗てうというようなと てろで, 流用して使っているというのが今までのやり 方であったと思うんですが，あっとよいあのというの は当然, どんどん要求されてきますので，今まである あのを使っていたのでは間にあわなくなって，あっと 最適化するために $5: 1$ がよいのか, または紡錐形のよ うなあのの方がよいのか, といったとてろはこれから かなり研究されるあのと思います。

井上あう一つ磁性材料についてお聞きしたいのは, 磁性材料は非常に分散が難かしいと思うのですが, 実 際どういうプロセスが現在とられているのかですね。 それから、さらにてういうとてろを何とかしたいと いうような，その辺のとてろを少しうかがわせてい ただければありがたいと思うのですが，いかがでしょ うか。

戸田(黒崎割業) 実は私，乙の仕事を始めてまだ 3 ケ月くらいでですね，あまりくわしいてとはわからな いんです。それで, 分散のプロセスというのはですね, 正直言ってなかなかで説明しにくいと申しますか，乙 こが実を申しますと各磁性粉メーカーのノウハウにな るとてろなものですから，ててら迅ば容赦願いたい と思うのですが。それで, 今, 我々がどういうとてろ で困っているか，というご質問だったかと思うんです が、てれにつきましては，まさにての分散なんです。 我々の製造プロセスというのはこの分散と凝集のくり 返しなんですね。特に最近の超微粒化の磁性粉, BET で言いますとだいたい 50 〜 60 クラスというのが当座 の目標になるわけですけれど屯，30くらいまでは，凝 集, 分散をくり返すのはかなりコントロールできるよ うになってきたと。とてろが $50 〜 60$, あっと微粒子 になってくると今までの延長線上で考えたのではどう あ解決できないというととで, 違う理論, ちがう発想 が必要になるんじゃないかと思っております。

小石 そういうフェライトの磁性粉をエンピツのた 
ばにして売った方がよいというメーカーと, 一個一個 シングルにして, 一本一本で売った方がいいというメ 一カーと 2 通り考え方があって, よ゙うせあとで並べる んだからタバにした方がよいというようなことをある テープ屋さんから聞いたことがあります。その辺の考 え方が最近は非常に進んできているようなんで，かな らずしあシングルでなくて，きちっと面でくっついた 開発をした方が面白いんじゃないか, という考え方を 聞いております。

それでは時間の都合, 湿式の方へ移る都合がござい ますので，乙こら辺で医薬関係の方に少し付着の問題 をうかがってみたいと思います。

墰上（名城大）固結のことで近沢先生に少しおうか がいしたいんですけれども，水溶性のものを取り扱っ ておりますと, たいがい $\mathrm{CRH}$ 付近で固結をおてすん ですけれども，その場合，テキストに書かれておりま すが,イオンに解離する場合, いったんイオンが CRH 以上で解離して，それがその解離したままだと固結を 起さないのでしょうか, ということと, それから乾燥 して CRH 以上になると今度はまたもとにあどって固 体ブリッジを作ると。そういうとてろで固結が起っ ているのか, その境目が非常に微妙なところでいつも 困っているんですが, どの辺で固結を起すか, という ことを様々やってみて, 我々のとてろでは, いったん C R H 以上になって，それが乾燥するときに固結を起 すという情報はつかんでいるんですけれ どあ, その辺の ところをお教え願いたいのですが。

近沢一般的に固結といいますけれども，水分によ る固結と, 食塩などですと加圧による一保存庫やサ

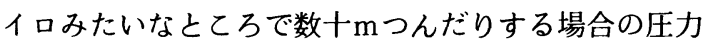
などによる—固結, あるいは, $\mathrm{KBr}$ の錠剂成形機み たいにプラスティックフローして固結するものなどが あります。水分に関してということであれば，例えば 食塩ですと，CRHが相対湿度で $75 \sim 6 \%$ 程度だと 思うんですが, 実際, どんなものであ、イオンであ分 子であそうなんだと思うんですが，安定度によって動 きやすさが違ってくる。例えば静電的に集塵した $\mathrm{NaCl}$ ですと, 電顥的にあアモルファスでして，そういった のは相対湿度で 0.0 何\%という非常に低湿度で表面積が 変動しているわけなんです。イオンが現在いる位置か ら他の場所へ移る場合の活性化(移動・拡散のための)エ ネルギーが水分子 1 個であ引っ張り込むとか, そうい う横方向の力が働けば落ち込んで, アモルファスな食 塩なんかであ非常に低圧でミクロ固結が起てります。 きれいな再結晶のあのですと, だいたい単分子ができ
た時点で表面積が動くとか, あるいは一定圧において も圧上昇が起乙って結局表面積が減って, トータルの 自由エナジーが咸る方向へ行くんです。ですから, 安 定なハロゲン化アルカリの場合でしたら単分子の水で イオン拡散が起っているみたいです。てれに対して $\mathrm{SO}_{4}{ }^{2-}$ のように 2 価の大きなイオンになったりします と, これは動いていないみたいで, 1 価のイオンの方 が動くようです。 $\mathrm{NaCl}$ と $\mathrm{K}_{2} \mathrm{SO}_{4}$ などで複分解反応 を少し調べたんですが， $\mathrm{K}_{2} \mathrm{SO}_{4}$ はじっとしていて， そちらに $\mathrm{Na}^{+}$とか $\mathrm{Cl}^{-}$が動いているんです。ですか ら，動きやすさというのには，安定度と大きさといっ たとてろが影響しているんだと思うんです。それから， 固結と言いますと,イオンの拡散が起って表面積が減 ったりとか, そういったとてろはあうミクロ固結と見 なしているんですが, 実際の粉体操作においては問題 になるようなとてろではないと思うんですね。一応我 々は, 水が吸着したてとによってイオンが表面拡散で きるようになったといったとてろでミクロ固結が起っ ているとしていますので，だいたい C R H よりは相当 低いです。それで, やはり固結が起る場合には, さき ほどお話がありましたが, 水分の経時振動, それから 温度の振動, そういったものがあって, 溶解・折出・ 固結ということになるんだろうと思います。飽和溶液 膜ができる厚み，というのは，例えば $\mathrm{KCl}$ なんかで すと, どんどん水膜ができていって, $1000 \AA$ とか $6000 \AA$ 亡か, だいたいそれくらいの厚みになってい ます。ですからCRHになりますと，それくらいの多 分子層の, 300 層くらいの水分子の層になっていると 考えられますし，ですから溶解量む非常に多くて，水 分振動や温度振動による溶解・折出量も大量になりま すから，本当にみた感じであ固まったかな，というも のになると思うのですが，連続的にミク口固結から規 模の大きい固結へ行っているんだ，と思っております。

飯田(名城大) 私がこの夏期シンポジウムに参加し たいと思いましたのは, 静電気のことについて少し勉 強しなければいけないと思ったからなんです。薬剤の 方では，例えば顆粒剂などを作ります時に，表面に高 分子などの被膜を作りまして, 特定の容器などに入れ ますと，顆粒剂が数珠玉の様に連なってしまいます。 てれは，おそらくは静電気的な力じゃないかと思いま して，そういうものを実祭に，純粋に測り出すことが できるのかどうか, それから，そういう付着力の中の 静電気的な力というものをどういう方向で測定したら いいのか, ということを考えておりまして,できまし たら東大の山本先生に少しそういうことについて何か 
コメントをいただければと思うのですが。

山本 どのくらいの粒径ですか。

飯田 顆粒剂の場合ですと普通 $1 \mathrm{~mm}$ から $2 \mathrm{~mm} く$ らいです。

山本 数珠玉についたまま, 例えばファラデーケー ジに入れてしまえば, トータルでの帯電量は簡単に測 れます。それから，1個 1 個で計リたいと思いました ら, 何か気流か何かの分散力をかけて, 1 個 1 個にわ けて，昨日少し打話したような通過型のファラデーケ ージの中へ入れればきれいにピークがでると思います。

飯田 それがその, 例えば, 平面との付着力に電気 的な力というあのがどのくらいの割合で支配している のか, ということについてはいかがでしょうか。かな り条件が難かしいかあ知れませんが。

山本 その場合, 実験的にあ計る方法もあるかと思 いますけれども, 例えば帯電量が測定できれば, 静電 気力は計算できるんじゃないかと思いますけれどあ。 あと, 実験的に測りたいと思えば, 遠心型, あるいは 振動型の付着力测定器で測定すれば何とかなると思い ます。

小石 他にあ医薬関係の方がいらっしゃるのですが, ちょっと時間の関係もございますので, あと大河原さ ん, スプレードライの方からみて何かコメントがでざ いましたら, マイクロカプセルなどやられております ので。

大河原 私共の方は液状物からそのまま粉体を作る ということをやっているわけですが, その場合に, ど ういう風に考えたらいいのか, というヒントみたいな あのを，今回あお話を聞いておりまして，ちょっとい ただきまして，ありがたいと思っております。それか ら, 実際に, スプレードライみたいなものでスラリー 状のあのとか溶液状のあのから粒子を作るわけなんで すけれどあ, 本当はできれば，そのできた粒子，粉体 そのあのの外側に何か機能性を持ったような，いわゆ る表面が改良されたようなあのが一挙にできるような あのができればなあ, と考えながら聞かせていただき ました。どうあありがとうございました。

小石では, 湿式の議論の方へ移ることにして, 司 会を井上先生にバトンタッチしたいと思います。

井上 スラリー関係の質問も2，3受けているんで すが，まず始めに，鈴木さんの方からの質問にありま した, 水和の問題について, この問題については小石 先生お願いします。

小石 固体と水の界面における水和ので質問ですが， 私共はセメントの水和をだいぶ以前にやりまして, 示
差熱のカロリーメーターを使って48時間ほよ゙分析した ことがあります。水和に関する研究は, 湿潤熱がわか りますと，水和熱を全部とらえることができるという ことで, それがセメント各社の出荷基準になりまして, 品質管理に使われています。例えばそういう装置を使 うと界面現象の水和は非常によくつかまります。それ からあとはDTAなどを使って, 熱分解によって結晶 水のとれるプロセスを追う方法があります。あう一つ 私は, 鉛酸カルシウムの水和をやったてとがあるんで すが，それは水の中でかきまわすと結晶水がとれてき て, だんだん色がかわってくるんです。この色の変化 を見ながらX線分析でいくということで，水和に関し てはX線による分析, 写真による形の変化, 水和熱, DTA，だいたいその辺でせめて行けば様々な現象が 解ける, という気がしております。水和に関するてと は非常に重要で，例えばものによっては非常にさらさ らな粉末になってしまうという現象がしばしばみられ ます。ちょっと時間の関係であまり十分なお答ではあ りませんが, そういうことがございます。

井上 濃厚スラリーの問題というのは, このシンポ ジゥムであしばしば様々な講演者の方から話題に出た んですが，あのによってとらえ方，とらえるための目的 あ非常に違うんですけれども，武崎さんの方からで質 問，あるいはどういうことを討論したいか, というこ とをちょっとで説明願います。

武崎 非常に濃厚な固液分散系におきましては, 希 薄なものに比べますと, 当然粒子同士の相互作用が大 きくなりまして，凝集という点から見れば非常に凝集 しゃすい系だと考えてよいと思うのですが, 我々の扱 っています高濃度スラリーについて, その安定性とい うことを考えますと, 今回の報告にありますように, 微粒子というあのの存在が重要になります。そして, 微粒子が存在してくるとなると, 今度はまた, この微 粒子は大きな粒子に比べたら凝集しやすい方向にある わけですね。実際にそのスラリーの安定性を向上させ るためには，昨日仙名先生の方から様々ご指摘がありま したけれどあ, 結局のとてろは, 弱い凝集状態を保つ, 維持するということが, ある程度の降伏値の発生につ ながって, 長期的なスラリ一の安定性につながると考 えているんですが，そしてその凝集状態を，ある程度， その, 微粒子によって生じさせているあのと考えてよ いのだろうと思うわけです。そして，乙うなりますと 今度は, どの辺までゆるされるのか, 緩慢な凝集が, どこで急速な凝集に変わってしまうのかという見極め, というかあるいは限界点というか, その辺がどうなる 
のか, という点なんですが。

井上川島先生, この今の様な, 非常に濃厚なスラ リーの凝集, というあの, あるいはそのスラリーの安 定性とかですね, 固化とか, そういう風なととについ て, どのような評価基準が必要なのか, といったてと について, 何かコメントをいただけませんでしょうか。

川島(岐阜薬大) いわゆる安定性というのは, 二つ の側面から見られると思うんですが，一つは非常に分 散しているあのが安定と言えるのか, あるいはかえっ て, 凝集したものが安定であるとも言えると思うんで すね。例えば薬品の場合で申しますと, 先程少しお話 にありましたように，むしろその系全体が凝集してい ると, それは違った側面から見れば大変よく安定して いるという風に言えると思うんですね。それで, 昨日 の仙名先生の拓話で, 降伏值があるから安定だという 言い方は扔かしい, と言われましたけれどあ, 私は逆 で,むしろその降伏值が出た，ということは，一つの， 逆の見方の安定性を計るメジャーになっている，とい うように私は理解しています。ですから何か一つの現 象というのは見方によって全く違うようだけれどあ, それは目的と言いますか, ニーズには非常にあったて とになるということで, そういった, 側面性があると いう様にとらえた方がよいと考えております。

小石 ちょっ之分野は違うんですけれど, 商品の具 体的な例を出してお答えしたいのですが, 我々はよく てういうボールペンを使って抢ります。てれは擋拌が ありませんから, 詰ったら全部出なくなります。それ で, この系の分散が非常に難しいわけです。様々な文 具メーカーはミリポアフィルターを使って濃厚スラリ 一の系を押し出して, 例えば $0.1 \mu \mathrm{m}$ の穴を粒子が全部 通るようなあのはよいとか，それ以上はカットすると かするんですね。そういうミリポアフィルターの径を かえて分散の安定性をチェックしているのが普通の考 え方です。磁性粉に関するアメリカの研究では, N$\mathrm{S}$ がリングストラクチャーを作ると, 一番ス夕、゙リテ イがよいと言われております。それで, 極限粘度を測 る際に擋拌している時はいいんですが, 止めるとリン グストラクチャーができて, 極限粘度が少し高めにな ります。したがってそのような分散ができればスタビ リティーがあるということで, 濃厚分散系について考 えますと，ある意味では強引に吸着して押し込んで行 って，樹脂の層を作ってしまう。リングストラクチ ャーが今のソフトフロックにいいんじゃないか, とい うことですね。石炭の場合はちょっと粒子が大きすぎ るのでそういう議論はできないんですけれど屯, サブ
ミクロンの粒子では，それが一番スタビリティーがよ いということです。それが，見掛けの降伏值を持った ある嵩のある系である, ということで, 修正液の力チ ヤカチャとボールを入れてふる，というのはまさに， そのストラクチャーを作らせる, メカノケミカルなノ ウハウが入っているわけです。そして, そのリングス トラクチャーは, SEM を使って写真で見ますと, 間 違いなく解りますので, 写真をベースにして粉は考 えた方がよい，というのが私の考え方です。文房具は 一番難しい, 一番いい例だと思います。

井上 CWMは非常に，できるだけ高濃度なサスペ ンションの一例だと思うのですが, 割とてれに似たよ うなものに, 例えばアルミ精練で出てくる赤泥があり ます。乙れは酸化鉄を主体とした非常に大量のマッド なんですが，乙れは例えばフィルタープレスで沪過し ますと，板状のかなりてちてちのケークができるんで すけれどあ，てれをプラスティックの袋に入れていわ ゆる捏ねる，というか練り返えすということをいたし ますと，再びスラリー状になってしまいます。それで, 例えばトラックで運んでいるうちに流状化してしまう というととで, 逆に流状化するとたいへん困る例にな るわけです。その辺の, ケークの状態から非常に濃厚 なスラリーとの間のコントロールをいかにうまくやる か, ということがかなり, てれから先のテクノロジー として重要な課題ではないかと思うわけですね。それ に対してはもちろん, 界面活性剂などの物質によって 表面をコントロールする，ということになるかと思う んですが, 先程武崎さんの括話で出たかと思いますが, $0.5 \%$ とか $1 \%$ とかいうあのを非常に大量に一一数千 万トンのオーダーで使うあのに用いることになります と, 界面活性剤は日本中のものをあつめても足らない 様なととになります。乙の辺, だいたい 1 \%というの は乙ういうスラリーに対してどの程度の值であるのか, 何分子層の皮膜であるのか, という風な乙とについて, 武崎さんの方からちょっと問題提起をしていただいて, そのあと界面活性剤のメーカーさんもたくさんいらっ しゃるので，扣話をうかがえたらと思うのですが。

武崎 今, 井上先生がおっしゃったように, 加えま した添加剤が実際どの様に吸着しているかという点に ついて，それが単分子の層で着いているのか，それと あ多層で着いているのか, という点についてはあまり はっきりとは把握できていません。ただ，加え方の点 から言えば，一度に加えるんじゃなくて，多段で入れ てやってなるべく均一に着くようにしてやるという方 向では検討は進めています。それで, 実際に, ボール 
ミルで，砕く時に添加して着けた界面活性剤がどのく らい有効に㗢いているかというのは，昨日申し上げま したように一つの評価法として使っていますのが，ナ フタレンということで, ベンゼン環を分光光度計で測 りまして，その吸着量を出すのですが，その量がだい たい7割くらいついている状態がよくて，逆にそれ以 上着き過ぎるとまずい，というような傾向があるとい うのはつかんでいるんですが，実際に分子がどのよう に吸着しているか，というとてろまでは明確になって いないような状態なんです。

竹内 あまりくわしくないので，一般的なお話にな ってしまうかとあ思うんですが，界面活性剂にあ，ア ルキル基が一つ長いのがあって，その先に親水基がひ とつだけあるという，いわゆるオタマジャクシのかっ こうで書ける界面活性剤がでざいます。それから，活 性剤といいますのは，合成のあのはだいたい，アルキ

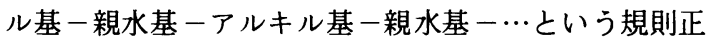
しい構造をしているあのがほとんどと言っていいかと思 います。それで，ポリエチレンオキサイトとか，そん なようなものが割と少量の添加でもって完全な分散で はなくて，凝結の防止といいますか，そういうあのに 効果があるということです。その時の吸着状態という ことについては，推定ではありますが，やはり吸着と いうのは似たあの同士が付くということでして，扔そ らく、クリーンなカーボンブラックの無極性のあので したら，乙れはあうきれいに，蹯水基を固体側に向け て水の側親水基を向けるっていう傾向がはっきり出 てまいるあのですから，非常に説明がしやすいんです が，石炭のように，てういろいろへテロな性質を持っ ている表面のとてろは全然クリアな説明はできません で, どちらかと言えば, 親水基は灰分のところに，ナ フタレン環は疎水性のとてろにくっ付くということだ ろうと思います。それで,ナフタレン環の場合は割と ベタッとくっつく配向を持つようです。染料ですとか, 他の材料で調べた結果では, 割とべタッとくっついて, 一分子当りの専有面積は割と大きくなるので，比較的 少量できくということになります。乙れに対して，始 めに申し上げたようなオタマジャクシタイプの界面活 性剂で効果を上げようとしますと, 垂直に伸びたよう なかってうのとてろ、また，それが逆さまになったよ うなところ，ということで吸着層が厚くなるものです から，どうしても効果を出すためにたくさんの添加量 が必要になってしまいます。したがって，分子専有面 積が大きくて, 安くて，それで，効果ですけれども， 親水基のとてろの水和層であって適当に凝集を防止す
るとかいうような効果できいているんじゃないか，と いうように推定しております。

鈴木 原理的なで説明は今あったようなてとだと思 います。丁度よい比較例として今気が付いたんですけ れども，高分子凝集剂でいわゆる S S 沈殿させる場 合ですと、だいたい添加量としましては，入っている SS の量にもよりますが, 水あたりでいいますとせい ぜい数 ppmというオーダーが多いんですが，一方，い わゆるパックとかと称して抢ります無機の塩類を用い ますと，その場合はやはり数百 ppmから $1 \%$ という例 が多くなります。丁度今の括話でも，添加量の比較で 言いますと，何かその辺に比例的な関係があるように 思われます。それで，石炭の表面にどういう形で吸着 して，それが安定性を保つというのはどういう原理な んだろうか，ということですが，一つには，最後に掠 話がありましたように，水和という形を保つことがひ とつの安定性に関係があるということででざいます。 高分子凝集剂の凝集状態というのはどういうものかと いうと，今までに説明されているのによりますと，夕 コの足のように高分子の凝集剂が水に溶けた状態でい て，それが粒子にからみついて 1 個の粒子を 2 個にし， さらにフロックを作ってどんどん大きくなっていくん だとされて抲ます。その場合，どうあ，むともとあ る SS 粒子む実は水の鞘を持っているんじゃないかと 思いますし，高分子屯水に溶けるためには水和しないと 溶けないということがありまして，その辺が何か複雑 に関係しているんじゃないかと思っております。それ で，ある時突然高分子が効かなくなるというのは，塩 類濃度が高いと手が伸びないということで，またそれ は水和との様々な関係があるんじゃないかと思いまし て、そういう点では面白いヒントだと思いますんで， ひとつての辺を研究させていただきたいと思います。

川島 先程の話に飛んであよろしいでしょうか。竹 内さんの拓話を聞いて非常に同感したとてろがあるん ですが，例えば作る—例えば充堤性をあげるためによ゙ ういった形の結晶を作るか，といった問題ですね。そ れから，その結晶をいかに細くするか，とかあるいは そのプロセスをいかに短縮するか，というお話をうか がったわけです。それについて私たちが考えているの はこういうことなんです。今までの粉体のプロセスと いうのは，既に様々な結晶があって，乙ういう粒子が あるので，それを使って何か加工する，とか，プロセ スをうまくする，という話が多かったと思うんです。 それをそうではなくて，粒子，あるいは結晶というの は，一番最初は再結晶などで，要するに溶液の中から 
出てくるわけですね。ですからそのでてくる時にその 粒子を加工してしまう，とすれば，いったん空気中に とり出してそれをまた水の中に戻す，というょうなプ ロセスが省けるんじゃないかということで，粒子を作 りながら作る時に例えば加工してしまうというような プロセスっていうのがてれから非常に重要になると思 うんです。そういうょうな形で粒子の設計ですとか粒 子の加工をやる，といったてとを将来やっていきたい と思っています。特に医薬の場合ですと，例えば，い かにその表面エネルギーの高い結晶を作るか, とかで すね, あるいは結局それが溶解性の問題とか溶解速度 の問題とかにつながるかと思うんですが，そういった， その粒子を作るっていう点ですね，そういったてとが てれからひとつの，粉体工学の方向になるんじゃない かと思います。それは，粒子の機能性を上げると いうととと、プロセスをいかに効摔化するか，と いう 2 つの観点からですね。ちょっと濃厚スラリーの 話とは別になってしまいましたが。

小石さっきの石炭の話ですが, 石炭の上に様々な 油がくっついています。私が以前やりましたのは, 力 ーボンブラックをソックスレーのアルコール・アセト ンで抽出しますと、様々な粘着物が出てまいります。 てれと相溶性のよい界面活性剂を使った方がコールの ディスパージョンはよい，というのが私の考え方です。 したがって，その粘着物質と活性剂の混ざったすのが 吸着をしている。あるいは付着しているんで, 活性剂 はどちらかというとそれに一回溶けた形で, コアセル ベート的な，単分子膜のような吸着であって，きちっ とした配向は考えられないんじゃないか，という疑問 を前から持っております。乙れはCOMをやった時の 結果なんですが, それで, 石炭は薄層に剝れてまいり ますから, 結局粉砕して行きますと無限に表面積が増 えるというわけで, 見かけの粒度分布っていうのはあ まり確かじゃないんですね。だからその辺の解釈から 考えますと，まずソックスレー抽出をして，出てきた ペースト状のあのに, ベンゼン・ナフタレン環の相溶 性が結構よいという，そてから話を起こさないと，吸 着では答が出ないという考え方を私自身は持っており ます。乙れは時間の都合上省略しますが，過去にやり ました結論から，そういうとてろの不純物をまず議論 しないと分散は何がよいのか出せないと思っておりま
す。

さて、それでは締めくくりででざいます。たいへん 長い時間, いろいろとで議論いただきまして, で発言 の機会の無かった方もいらっしゃるかと思いますが, 今日は工学的な表面の問題と理学的な表面の問題につ いて、それをドライとウェットの系から，界面現象を いろいろ考えてきまして, 大半の議論は出尽したよう な感じがいたします。まだいろいろな話題提供が, 界 面現象についてはたくさんあるような気はいたします ので，また，てういうあのを整理しまして，てのよう な機会を作りたいと思います。そしてそてでは，粒子 を大きさで分けて考えて，そのような中で界面現象の 議論などをしていくと，あっと煮つまるのではなかろ うか，というような感じがいたします。では最後に井 上先生にで挨拶をお願いしたいと思います。

井上 今さら “で挨拶”ということでもでざいませ んので，すぐ終りにしたいと思いますが，一つだけ， 実は粉体工学会にはいくつかのグループ会というのが でざいまして，ある特定のテーマについての意見交換 の場を設けているわけででざいます。そのグループ会 の一つとして，新しく，本年度の途中から，「粉体の 表面物性と改質」というテーマで, 丁度今回のシンポ ジゥムとほぼ同じようなニュアンスのグループ会を, 宇都宮大学の宇津木先生が世話人になってお始めにな ります。たぶん第一回の会合は11月くらいになるかと 思います。DM 等で直接会合の予定などを個人的にお 受け取りになりますためには，粉体工学会誌を注意深く 見ていただきますと， 8 月号か 9 月号に会員の募集が 出るはずですので，お忘れなくハガキを出しいただ けるようにと思います。

それでは，大変長い時間にわたりまして，熱心にで 討論いただきまして，主催者としてたいへんありがた く存じます。で協力いただきました先生方，特に東京 でいろいろで相談に乗っていただきました小石先生を 始めとする先生方に厚く扔礼を申し上げますとともに， 非常に面白い話題をそれぞれに提供していただきま した講師の方々にも厚くお礼を申し上げたいと存じま す。あう一度, 講師の方々への拍手をむって会を閉じ たいと思います。よ゙うあありがとうございました。 (拍手)

（文責 東大生産技術研 松山, 山本） 